\title{
Gout - Risks, Comorbidities and Associations
}

\author{
CRISTINA DORINA PARVANESCUㄴ, ANDREEA LILI BARBULESCU²*, PAULINA LUCIA CIUREA ${ }^{3}$, BEATRICE ANDREEA CHISALAU ${ }^{1}$, \\ SINETA CRISTINA FIRULESCU ${ }^{1}$, ADINA TURCU STIOLICA ${ }^{4}$, STEFAN CRISTIAN DINESCU ${ }^{3}$, RALUCA ELENA SANDU ${ }^{5}$, \\ CARMEN VALERIA ALBU ${ }^{6}$, HORATIU VALERIU POPOVICIU ${ }^{7}$, RAZVAN ADRIAN IONESCU, FLORENTIN ANANU VREJ U ${ }^{3}$ \\ 'University of Medicine and Pharmacy of Craiova, 2 Petru Rares Str., 200349 Craiova, Romania \\ 2University of Medicine and Pharmacy of Craiova, Pharmacology Department, 2 Petru Rares Str., 200349, Craiova, Romania \\ 3University of Medicine and Pharmacy of Craiova, Rheumatology Department, 2 Petru Rares Str., 200349, Craiova, Romania \\ ${ }^{4}$ University of Medicine and Pharmacy of Craiova, Pharmacoeconomics Department, 2 Petru Rares Str., 200349, Craiova, Romania \\ EUniversity of Medicine and Pharmacy of Craiova, Biochemistry Department, 2 Petru Rares Str., 200349, Craiova, Romania \\ שUniversity of Medicine and Pharmacy of Craiova, Neurology Department, 2 Petru Rares Str., 200349, Craiova, Romania \\ 7University of Medicine, Pharmacy, Science and Technology of Targu Mures,Department of Rheumatology, BFK and Medical \\ Rehabilitation, 38 Gheorghe Marinescu Str., 540139, Targu Mures, Romania \\ ${ }^{8}$ Carol Davila University of Medicine and Pharmacy Bucuresti, 3rd Internal Medicine Department, 37 Dionisie Lupu Str., \\ 020021, Bucharest, Romania
}

\begin{abstract}
Being the most common inflammatory arthritis, gout is highly associated to several comorbidities that have importantconsequences on patient's prognosis and are related to a frequent premature mortality. The study aimed to analyse the type and frequency of gouty arthritis related comorbidities, by testing for correlations between plasma level of uric acid and a series of clinical features and laboratory markers associated with inflammatory status, metabolic abdormalities and systemic complications. After analysing the results, we noticed the presence of comorbidities in signficant percentages, directly correlated to serum uric acid levels. Ou observations underline the necesity of a complex evaluation, in order to reveal even subclinical associated pathologies and prevent possible events, with an input on patients' prognosis.
\end{abstract}

Keywords: gout, metabolic syndrome, comorbidities

Gout represents a group of diseases bound by a set of common features linked with tissue deposition of urate crystals, a phenomenon which occurs in the setting of hyperuricemia (HU), i.e. when uric acid (UA) levels exceed solubility threshold [1-6]. By this definition, prolonged HU can lead to deposits of urate compounds in joints, periarticular tissue and, also, in visceral organs. The disease can occur, either as an asymptomatic HU status, or as an overt clinical entity. The latter may manifest in the form of acute gouty arthritis (GA), chronic tophaceous gout with either articular symptoms or extraarticular involvement, such as nephrolithiasis or other visceral sites [4].

The rising global incidence and the strong impact on the patient, as a result of both disease and socio-economic burden, add up to the inherent challenge of this disease, although it is commonly viewed as easily manageable. Clinical implications of gout extent beyond the typical crystal deposits in joints and may potentially lead to cardiovascular, renal and neurological complications. Evaluating such patients might represent a challenge, taking under consideration the possible subclinical comorbidities and their input on patients' prognosis and quality of life. Along with laboratory studies, imaging methods permit an early diagnosis with identification of associated pathologies and individualized therapeutic measures [7-22].

Scientific research performed over the last century has consistently addressed the association between gout and arterial hypertension (AHT), diabetes mellitus, obesity, urate nephropathy and neurologic disease [23] .

\section{Experimental part}

The study aimed to analyse the type and frequency of GA-related co-morbidities, by testing for correlations between plasma level of UA and a series of clinical features and laboratory markers associated with inflammatory status, metabolic abdormalities and systemic complications.

\section{Material and methods}

We performed a retrospective study on 31 patients diagnosed with GA based on established ACR/EULAR 2015 criteria [24], in a two year interval between 2016-2017, admitted to the Rheumatology Department of the Emergency County Hospital Craiova, and a control group, of 27 sex and age-matched subjects, without acute or chronic inflammatory diseases. Patients data obtained included demographic, clinical and laboratory parameters and were collected from every patient in accordance to the study protocol. Laboratory tests performed on a broader group of patients with clinical suspicion of GA resulted in the diagnosis confirmation and, thus, led to a final study group of 31 patients on which further bio-clinical correlations were tested. Thus, the clinical evaluation was initially focused on patienthistory, disease history, number of tender and swollen joints. Inflammation markers included were $C$ reactive protein (CRP), erythrocyte sedimentation rate (ESR) and fibrinogen. Complete laboratory work-up consisted of plasma levels for ureea, creatinine, UA, lipids and glucose. Any clinical features of cardiac, renal, hepatic, neurological disease were noted. Also arterial blood pressure was measured for every patient. The study was performed in accordance with the ethics and deonthology principles of the Helsinki Human Right's Declaration. All patients provided their written informed consent, after receiving a standard form which mentioned that the results would be used for research purposes. 


\section{Results and disscusions}

Our study included 31 patients diagnosed with GA, predominantly male $(77,41 \%)$, with a male to female ratio of 3. 4:1. Mean age of patients with GA was $59.88 \pm 8.12$ years, with a global range between 45 and 79 years, with a mean disease history was $39.27 \pm 28.6$ months (table 1 ).

Analysing the pattern of associated comorbities in our study group, we reckoned the following results:

Table 1

BASELINE CHARACTERISTICS OF GA PATIENTS

\begin{tabular}{|l|l|}
\hline Characteristics & \\
\hline Age, $\mathbf{y}$ & $59.88 \pm 8.12$ \\
\hline Sex (M/F), n(\%) & $24(77.41) /(22.59)$ \\
\hline Mean BMI (kg/mp) & $26.73 \pm 4.13$ \\
\hline Hypertension, n(\%) & $20(64.51)$ \\
\hline SBP (mmHg) & $\mathbf{1 3 7 . 4 \pm 1 8 . 6 1}$ \\
\hline DBP (mmHg) & $80.32 \pm \mathbf{1 7 . 7 9}$ \\
\hline Glucose (mg/dL) & $92.30 \pm 12.73$ \\
\hline Hb (g/d) & $13.22 \pm 1.40$ \\
\hline ESR (mm/h) & $30.87 \pm 19.64$ \\
\hline CRP (mg/dL) & $9.21 \pm 11.59$ \\
\hline TGO (UI) & $23.86 \pm 9.36$ \\
\hline TGP (UI) & $26 \pm 11.54$ \\
\hline Cr $(\mathbf{m g} / \mathbf{d L})$ & $0.88 \pm 0.21$ \\
\hline UA & $7.49 \pm 2.14$ \\
\hline Total cholesterol (mg/dL) & $258.9 \pm 48.33$ \\
\hline LDL cholesterol (mg/dL) & $199.5 \pm 42.46$ \\
\hline TG (mg/dL) & $215.8 \pm 48.56$ \\
\hline Total lipemia (mg/dL) & $829.3 \pm 177.8$ \\
\hline NAFLD (N; \%) & $24(77.41 \%)$ \\
\hline
\end{tabular}

The results are presented as mean \pm standard deviation or percentages ( $n \%) ; B M I-b o d y$ mass index; SBP-systolic blood pressure; DBP-diastolic blood pressure; Hb-hemoglobin;ESR-erythrocyte sedimentation rate; $C R P$ - $C$ reactive protein; $\mathrm{Cr}$ creatinine;UA-uric acid; LDL cholesterol-low density cholesterol; TG-triglycerides; NAFLD-non-alcoholic fatty liver disease.

\section{Anemia}

Assessing hemoglobin $(\mathrm{Hb})$ levels, we registered a mean value of $13.22+1.40 \mathrm{mg} / \mathrm{dL}(\min 9.7, \max .15 .8)$, for 6 patients $(19.35 \%)$ registering values corresponding to anemia, most of them with a mild degree. For the control group, anemia was present only in one subject.

Values of serum uric acid (SUA) seem to be influenced just slightly by the level of $\mathrm{Hb}$. We obtained a low negative correlation between $\mathrm{UA}$ and $\mathrm{Hb}$, with $r=-0.31$. Thus, we can conclude that high levels of SUA tend to be associated with lower $\mathrm{Hb}$ (fig. 1).
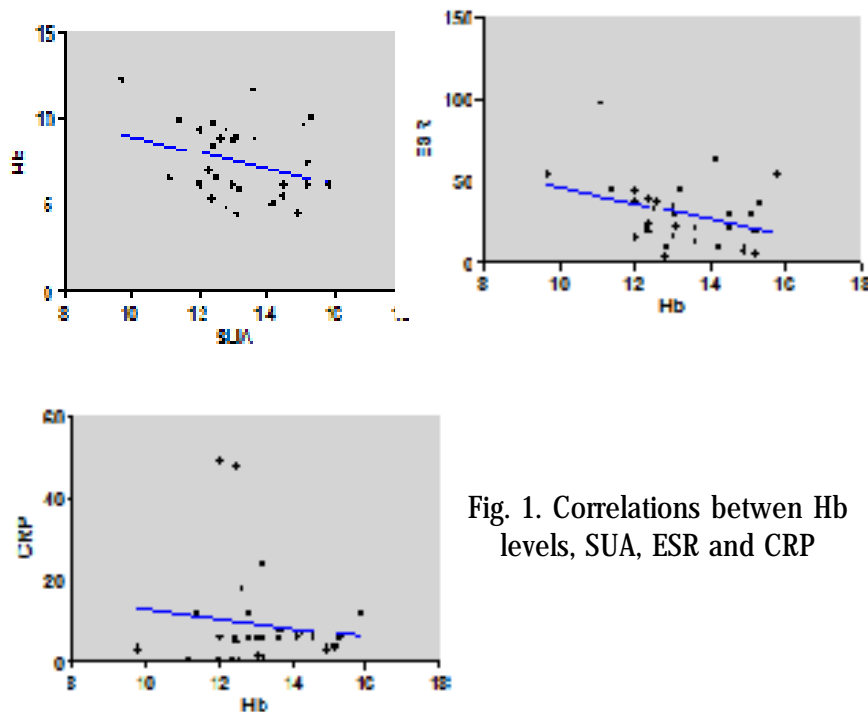

Fig. 1. Correlations betwen $\mathrm{Hb}$ levels, SUA, ESR and CRP
Although the value of Pearson correlation coefficient for the relation between $\mathrm{Hb}$ and ESR is only 0.33 , it is noted that lower $\mathrm{Hb}$ values are associated with with higher than normal ESR values.

The relative low number of patients, and method of enrollment, i.e. consecutive patients diagnosed with any form of GA, could have had an influence on the Hb-CRP correlation result, taking into account that the majority of patients were in the intercritic phase, thus having low CRP values.

$\mathrm{Hb}$ value could have also been influenced by the renal involvement. The negative correlation coefficient of -0.32 suggestan inverse relation between $\mathrm{Hb}$ and kidney disease. Although we did not find a statistically significant diference in the mean values, it is worth noticing that the lowest $\mathrm{Hb}$ values were recorded in patients with renal involvement (12.69 \pm 1.573 vs. $13.60 \pm 1.161, p=0.09)$ (fig. 2).

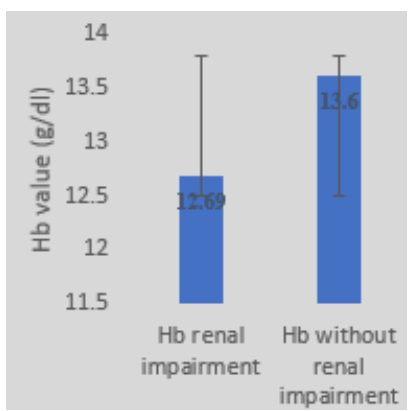

Fig. 2. $\mathrm{Hb}$ levels depending on the presence of CKD

\section{Cardiovascularinvolvement}

The presence of AHT was established for 20 patients (64.51\%), significantly different compared to control group (13; 48.14\%; $p=0.004)$.

Our data did not reveal a significantcorrelation between sistolic or diastolic blood pressure and plasma levels of UA $(r=-0.006$ and $r=0.01$, respectively). We considered therefore the need to evaluate a potential correlation between SUA levels and a prior diagnosis of AHT, taking into account that the results of the previous tests could be biased by a well managed blood pressure. Still, we could not find a relevant relation, neither betw een $\mathrm{AHT}$ and SUA levels $(r=-0.018)$, nor between any history of cardiac disease and SUA levels ( $p=0.18$ ) (fig. $3 a, b)$.
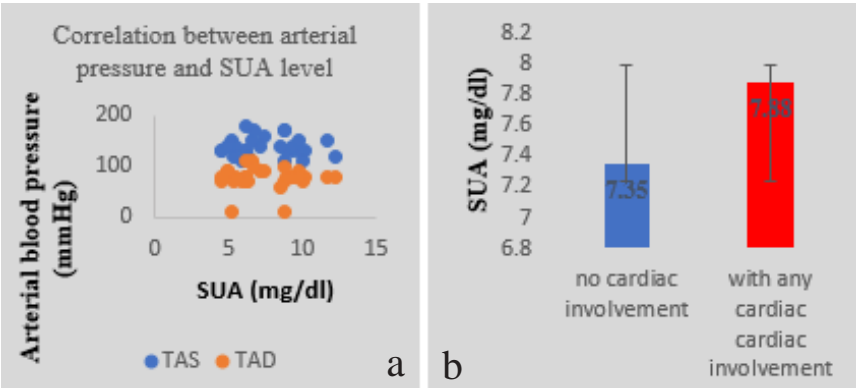

Fig. 3 a. Correlations between arterial pressure and SUA; b. SUA in patents with/without cardiac involvement

We carried outfurther statistical analysis on the possible correlation between ESR and blood pressure values, diagnosis of AHT or any history of cardiac disease. The results did not reveal significant correlation for any of the aformentioned parameters. Neither sistolic nor diastolic blood pressure influences the ESR value $(r=-0.22 / r=0.12)$. Increased ESR was not associated with any diagnosis history of cardiac disease. Similar results were obtained when analysing the values of CRP, which did not show any relevant correlation with blood pressure, nor with history cardiac disease.

Althoug the data obtained from our study group didn't demonstrate significant correlation between history of 
cardiac disease, inflammation markers and UA plasma levels, at the time of study inclusion, it is important to note the relatively high prevalence of $\mathrm{AHT}$ of $64.51 \%$, and also a significant prevalence of $25.8 \%$ for any cardiac disease history, among the patients in the study group (fig. 4). These observations can be attributed to the impact of long-term inflammation status, even though normal values of the inflammation markers were obtained at inclusion time.

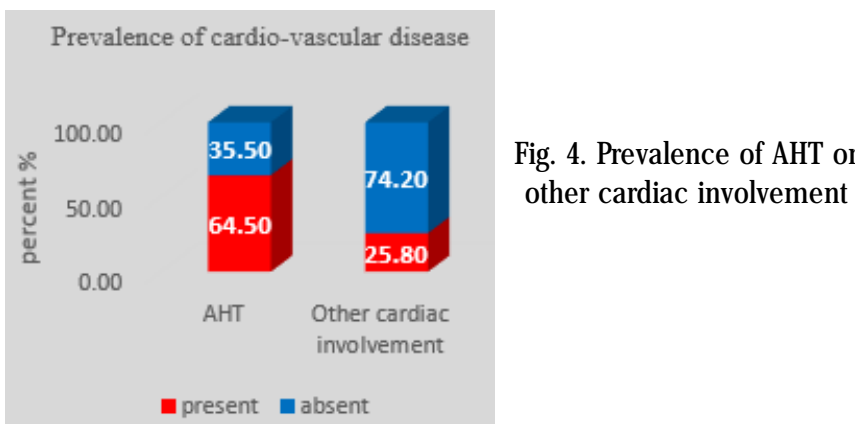

We also noted some demographic differences between patients, when adjusting for presence of AHT. Thus, the mean age for AHT patients was 60.55 years, significantly higher than the patients with normal blood pressure, which had a mean age of 56.18 years $(p=0.04)$. This suggests either a longer exposure to gout related inflammation, or an additional role of atherosclerosis development with age.

\section{Renal involvement}

Chronic kidney disease (CKD) was present for 12 of the patients (38.70\%) (fig. 5a), significantly different compared to control group (6; 22.22\%), $p=0.005$. Diagnosis of CKD among the study group could not be associated with SUA levels $(r=0.05)$, which can be explained by the fact that only a proportion of patients with hyperuricemia develop CKD. However, we noted a positive correlation between SUA and creatinine plasma levels $(r=0.45)$, when we adjust the analysis by age to the subgroup of patients under 60 years. Our data showed a trend for positive correlation between CKD and ESR though, but without statistically significant difference between the groups with/without CKD ( $p=0.29)$ (fig. 5b).

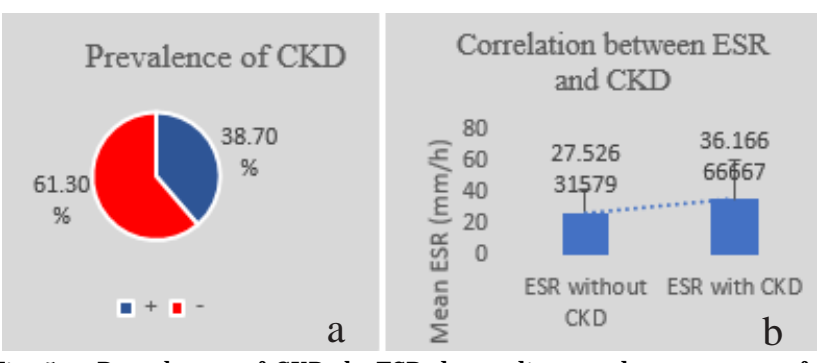

Fig. 5 a. Prevalence of CKD; b. ESR depending on the presence of CKD

\section{Hepatic involvement}

Although we did not find any direct correlation between UA levels and liver disease, over half of the patients had at least one episode of elevated liver enzymes (51.61\%). Most of our patients $(24 ; 77.41 \%)$ had fatty liver disease at ultrasound examination, significantly different compared to controls $(p<0.001)$, correlated with all lipidic parameters.

\section{Lipid and glucose metabolic abnormalities}

Among all biologic parameters that we analysed in our patient group, the lipid metabolism markers showed the most important association with both $\mathrm{HU}$ and inflammation. We obtained a pozitive correlation between $\mathrm{UA}$ and total lipemia levels $(r=0.31)$, while a negative correlation was observed between lipid levels and inflammation markers, especially in relation with ESR ( $r=$ -.035). We also noticed a positive correlation between total cholesterol and UA ( $r=0.507, p=0.0036)$, as for low density fraction ( $L D L$ cholesterol), $r=0.479, p=0.006$. For triglycerides we calculated a strong positively correlation $(r=0.780, p<0.001)$ (table 2).

\section{Table 2}

CORRELATIONS BETWEEN SUA AND LIPID PARAMETERS

\begin{tabular}{|l|l|l|l|l|}
\hline & $\begin{array}{l}\text { Total } \\
\text { cholesterol }\end{array}$ & $\begin{array}{l}\text { LDL } \\
\text { cholesterol }\end{array}$ & Triglycerides & Lipemia \\
\hline $\mathrm{r}$ & 0.5071 & 0.4798 & 0.7809 & 0.31 \\
\hline $\mathrm{p}$ & 0.0036 & 0.0063 & $<0.0001$ & 0.1070 \\
\hline
\end{tabular}

ESR value can be directly influenced by total lipemia, even in the absence of GA, by the means of electrostatic change on the surface of erythrocites. However, SUA levels seem to be associated with significant changes in lipid metabolism, which in turn could explain the high prevalence of atherosclerosis and stroke in hyperuricemic patients.

When we analysed our data for the effect of glucose metabolic status on other parameters, we did not obtain any correlation between glucose plasma level and SUA, creatinine or ESR. The level of CRP did reveal a positive correlation with glucose levels ( $r=0.37)$, but this cannot be interpreted in the setting of GA. However, 10 of our subjects $(32.25 \%)$, had blood glucose leveles over the limits, without any prior diagnosis of diabetes. Compared to control group, where only 2 subjects had altered blood glucose, the difference was statistically significant $(p=0.0027)$.

Rheumatic diseases and gout are particularly known to be associated with a high incidence of metabolic syndrome [17] and increased risk for premature death. Screening for any comorbidities, by laboratoryand imagistic methods, is always of maximum importance and responsibility when dealing with such patients [7-23].

Analysing the associated pathologies present in our cohort, we found anemia in 6 patients (19.35\%), for most of registering values corresponding to a mild one. Previous studies reported several explanations for anemia in gout patients, and it is noticed that an increased uric acid could be the result of an increased synthesis of nucleic acids, due to an erythropoietic response; also the consumption of non-steroidal anti-inflammatory drugs (NSAIDS) can produce gastrointestinal bleeding and consecutive anemia $[25,26]$.

It is well known that AHT is common among gout patients and although our results did not reveal a signifficant correlation between diastolic or sistolic blood pressure and plasma UA, it is important to notice a relatively high prevalence of AHT and history of any cardiac disease, possibly related to long term inflammation status $[27,28]$. The percentage of AHT found in our study (64.51\%) is similar to the one reported by the third National Health and Nutrition Examination Survey (NHANES), 69.1\% [29]. Other publications have also demonstrated an increased risk of gout in hypertensive cohorts and the association seems to be bidirectional [30-32]. It is reported that AHT is more frequent for both male and female hyperuricemic subjects, the risk increasing with age [33-35]. A recent study, published in 2017, that included over 2000 patients, concluded that SUA is associated with an inadequate BP control and an increased arterial stiffness [36]. Another report, from 2016, concluded that SUA is an important determinant of BP, independent of lifestyle changes [37], data sustained by several other studies [38-40]. The 
bidirectional inter-relation between AHT and gout can be explained by different hypoteses, one of them being represented by glomerulosclerosis and consecutive, renal impairment with reduced renal excretion of urate [32]. Anoher important factor related to high SUA levels is the increased systemic and renal resistance. It is also important not to neglect the input of AHT medication on SUA level (eg. diuretics, beta blockers, non-losartan angiotensin II receptor blockers or angiotensin converting enzyme inhibitors) [41]. SUA has also been reported to be associated to vascular remodeling, endothelial dysfunction, renin angiotensin system activation, processess that promote the pathogenic pathways of hypertension [4244].

Our data have also showed the presence of CKD in a percentage of 39 among GA patients, and although it could not be associated to SUA, we noticed a positive correlation between SUA and creatinine levels in patients under 60 years. Several processes interfere with renal function and contribute to a decrease renal function, such as nephrolitiasis and interstitial nephritis, formation of cristals in renal tubules, deposits in renal medulla, glomerulosclerosis consecutive to AHT, use of non-steroidal antiinflammatory drugs (NSAIDS) [45-47]. A significant metaanalysis, that included thirteen studies and over 190000 subjects, concluded thatSUA is significantly positively interrelated to new onsetCKD, in patients with previous normal renal function [48].

The relationship between SUA and increased blood glucose, described from the nineteenth century [49], was not obtained from our group analysis, possible due to a relative low number of subjects, but it worth mentioning that over 30\% had blood glucose values over the limits. Furthermore, the risk of diabets has been linked to gout, particulary to SUA levels, and the association is more obvious among women. The higher risk of diabetes among patients with hyperuricemia may have several possible explanation: first we have to take under consideration the constant inflammation that might promote the beginning of pathogenic pathways in diabetes, as the high levels of insuline associated with an increased SUA level also determine a reduced renal excretion of urate.

Regarding hepatic involvement a recent meta-analysis, from 2016, that included over 55000 subjects, demonstrated that SUA level is related to a high risk of NAFLD, indepenedent of classic risk factors [50], as the meta-analysis that included over 28000 patients, that had the same conclusion, both in men or women, in Asian population [51]. Our results showed the presence of fatty liver disease for most of the patients.

\section{Conclusions}

Because gout represents the most common inflammatory joint disease and is associated with an increased risk of premature death, due to a common and highly association with all the components of metabolic syndrome, it represents a challenge in clinical practice, and itmight be tricking regarding subclinical comorbidities. Every patients should be carefully and periodically evaluated, by a multidiscipllinary team, in order to prevent the possible events and improve the prognosis of these patients. Although our study included a relative low number of subjects, the results are comparable to the ones already published and underline the necessity of a complete investigation for any alarm symptom, that can uncover a subclinical associated pathology.

\section{References}

1.SIMKIN, G. N., EDINBURGH, P.A., A concise history of gout and hyperuricemia and their treatment, Arthritis Res Ther, $\mathbf{8}$, suppl. 1 , 2006, doi: 10.1186/ar1906

2.ZHU, Y., PANDYA, B.J., CHOI, H.K., Prevalence of gout and hyperuricemia in the US general population, Arthritis Rheumatism, 63, nr.10, 2011, p.3136-3141.

3.SARAWATE, C.A., PATEL, P.A., SCHUMACHER, H.R., YANG, W., BREWER, K.K., BAKST, A.W., Serum urate levels and gout flares: analysis from managed care data, J. Clin. Rheumatol., 12, nr.2, 2006, p.61-65.

4.BURT, H.M., DUTT, Y.C., Growth of monosodium urate monohydrate crystals: effect of cartilage and synovial fluid components on in vitro growth rates, Ann Rheum Dis., 40, nr.10, 1986, p.858-864.

5.RODDY, E., DOHERTY, M., Epidemiology of gout, Arthritis Res\& Ther., 12, nr.6, 2010, p.223.

6.TOMITA, M., MIZUNO, S., YAMANAKA, H., HOSODA, Y., SAKUMA, K., MATUOKA, Y., ODAKA, M., YAMAGUCHI, M., YOSIDA, H., MORISAWA, H., MURAYAMA, T., Does hyperuricemia affect mortality? A prospective cohort study of J apanese male workers, J Epidemiol., 10, nr.6, 2000, p. 403-409.

7.BARBULESCU, A.L., CIUREA, P.L., MITRAN, C., CHISALAU, B.A., PARVANESCU, C.D., FIRULESCU, S.C., BALASOIU, M., BOLDENAU, M.V., POPOVICIU, H., VREJU, F.A., High frequency ultrasonography of the hand versus anti-RA33 evaluation in early rheumatoid arthritis - a pilot study, Med Ultrason, 19, nr.2, 2017, p. 166-171.

8.VREJU, F.A., CIUREA, M.E., POPA, D., POPA, F., PARVANESCU, C.D., CHISALAU, B.A., BARBULESCU, A.L., PARVANESCU, V., ROSU, A., CIUREA, P.L., Ultrasonography in the diagnosis and management of noninflammatory conditions of the hand and wrist, Med Ultrason, 18, nr.1, 2016, p. 90-95.

9.CIUREA, M.E., CIUREA, R.N., BARBULESCU, A.L., CHISALAU A.B., PARVANESCU, C.D., FIRULESCU, S.C., COVEI BANICIOIU, S., CIUREA, P.L., VREJU, A.F. Intramuscular hemangioma of the arm: ultrasonography and pathology features, Rom J Morph Embryol, 57, nr.2, 2016, p. 521-524.

10.FILIPPOU, G., SCIRE, C.A., ADINOLFI, A., DAMJANOV, N.S., CARRARA, G., BRUYN, G.A.W., CAZENAVE, T., D'AGOSTINO, M.A., DELLE SEDIE, A., DI SABATINO, V., DIAZ CORTES, M.E., FILIPPUCCI. E., GANDJBAKHCH, F., GUTIERREZ, M., MACCARTER, D.K., MICU, M., MOLLER PARERA, I., MOUTERDE, G., MORTADA, M.A., NAREDO, E., PINEDA, C., PORTA, F., REGINATO, A.M., SATULU, I., SCHMIDT, W.A., SERBAN, T., TERSLEV, L., VLAD, V., VREJU, F.A., ZUFFEREY, P., BOZIOS, P., TOSCANO, C., PICERNO, V., IAGNOCCO, A., Identification of calcium pyrophosphate deposition disease (CPPD) by ultrasound: reliability of the OMERACT definitions in an extended set of joints-an international multiobserver study by the OMERACT Calcium Pyrophosphate Deposition Disease Ultrasound Subtask Force, Ann Rheum Dis, 77, nr.8, 2018, p. 1195-1200.

11.BARBULESCU, A.L., VREJU, A.F., BUGA, A.M., SANDU, R.E., CRIVEANU, C., TUDORASCU, D.R., GHEONEA, I.A., CIUREA, P.L., Vascular endothelial growth factor in systemic lupus erythematosus - correlations with disease activity and nailfold capillaroscopy changes, Rom J Morphol Embryol., 56, nr.3, 2015, p.1011-1016.

12.FIRULESCU, S.C., TUDORASCU, D.R., PARAANESCU, C.D., CHISALAU, A.B., BASTIAN, A.E., EFREM, I.C., BARBULESCU, A.L., FORTOFOIU, M.C., CRIVEANU, C., IONESCU, P., DINESCU, S.C., TUDORANCEA, A.D., CIUREA, P.L., VREJU, A.F., The role of skin and muscle biopsy in the diagnosis of main connective tissue diseases, Rom J Morphol Embryol., 59, nr.1, 2018, p.55-64.

13.CODRINA, A., POMIRLEANU, C., IORDACHE, C., FATU, A.M., POPESCU, E., ANCUTA, E., MIHAILOV, C. Periodontal Disease and Lipid Profile in Systemic Sclerosis: an EUSTAR Cohort Experience, Rev. Chim. (Bucharest), 68, no. 4, 2017, p. 890-893. 
14. SAVA, I. SAVA, A. SAPTE, E., MIHAILOV, C., DUMITRESCU, G., POEATA, I., SAVA, F., HABA, D. Intraventricular metastatic clear cell renal carcinoma. Rom J Morphol Embryol., 54, nr.2, 2013, p. 44750.

15.CATALIN, B., CUPIDO, A., IANCAU, M., ALBU, C.V., KIRCHHOFF, F., Microglia: first responders in the central nervous system, Rom J Morphol Embryol., 54, nr.3, 2013, p. 467-472.

16.MUSTAFA, E.R., FIRULESCU, S.C., PARVANESCU, C.D., CHISALAU, B.A., TARTEA, G.C., EFREM, I.C., BARBULESCU, A.L., DINESCU, S.C., CIUREA, P.L., RADU, L, Triple valve endocarditis-a late diagnosis, J ournal of Mind and Medical Sciences, 5, nr.1, 2018, p.141-144.

17.SANDU, R.E., UZONI, A., COMAN, C., POPA-WAGNER, A., Cerebral ischemia in the aged. Limited anti-inflammatory efficacy of the indomethacin treatment, Rom J Morphol Embryol., 56, nr.3, 2015, 1111-7.

18.SANDU, R.E., DUMBRAVA, D., SURUGIU, R., GLAVAN, D.G., GRESITA, A., PETCU, E.B., Cellular and Molecular Mechanisms Underlying NonPharmaceutical Ischemic Stroke Therapy in Aged Subjects, Int J Mol Sci., 29, nr.1, 2017, pii: E99. doi: 10.3390/ijms19010099.

19. SANDU, R.E., BUGA, A.M., UZONI, A, PETCU, E.B., POPA-WAGNER, A., Neuroinflammation and comorbidities are frequently ignored factors in CNS pathology, Neural Regen Res., 10, nr.9, 2015, p.1349-55. 20.ALBU, C.V., PADUREANU, V., BOLDEANU, M.V., BUMBEA, A.M., ENESCU, A.S., ALBULESCU, D.M., SILOSI, C.A., ENESCU, A., Vascular neurocognitive disorders and the vascular risk factors, Journal of mind and medical sciences, 5, nr.1, 2018, p. 7-15.

21.TAISESCU, C.I., BICIUSCA, V., SAS, L., CAMEN, G., SAS, T., ALBU, C., TAISESCU, O., Changes of Visual Evoked Potentials in Patients with Thyroid Dysfunction,Rev. Chim. (Bucharest), 70, no.3, 2019, p. 961968.

22.TOADER, L.E., ROSU, G.C., CATALIN, B., PIRICI, I., GILCEAVA, I.C., ALBU, V.C., ISTRATE-OFITERU, A.M., MURESANU, D.F., PIRICI, D., Cerebrolysin increases motor recovery and decreases inflammation in a mouse model of autoimmune encephalitis, Rom J Morphol Embryol., 59, nr.3, 2018, p.755-762.

23.OH, H., PARK, J., YOON, Y., SEO, W., Comparisons of the Incidence and Critical Risk Factors of Metabolic Syndrome in Patients With Rheumatic Disease or Gout, Orthop. Nurs., 38, nr. 3, 2019, p. 201-208. 24.NEOGI, T., TIM, L.T.H., JANSEN, A., DALBETH, N., FRANSEN, J., SCHUMACHER, R. H., DIANNE BERENDSEN,4 MELANIE BROWN,6 HYON CHOI,1 N. LAWRENCE EDWARDS,7 HEIN J. E. M. JANSSENS,4 FREDERIC LIOTE,8 RAYMOND P. NADEN,9 GEORGE NUKI,10 ALEXIS OGDIE,5 FERNANDO PEREZ-RUIZ,11 KENNETH SAAG,12 J ASVINDER A. SINGH,13J OHN S. SUNDY,14 ANNE-KATHRIN TAUSCHE,15J ANITZIA VAQUEZ-MELLADO,16STEVEN A. YAROW S,17 AND W ILLIAM J. TAYLO, MCADAMS-DEMARCO, M.A., MAYNARD, J.W., CORESH, J., BAER, A.N., Anemia and the onset of gout in a population-based cohort of adults: Atherosclerosis Risk in Communities study, Arthritis Res Ther., 14, nr.4, 2012, R193.

25.REYNOLDS, M.D., Gout and hyperuricemia associated with sicklecell anemia, Semin Arthritis Rheum., 12, nr.4, 1983, p.404-413.

26.CULLETON, B.F., LARSON, M.G., KANNEL, W.B., LEVY, D., Serum uric acid and risk for cardiovascular disease and death: the Framingham Heart Study, Ann Int Med, 131, nr.1, 1999, p. 7-13.

27.DAVEY SMITH, G., LAWLOR, D.A., HARBORD, R., TIMPSON, N., RUMLEY, A., LOWE, G.D., DAY, I.N., EBRAHIM, S., Association of C-reactive protein with blood pressure and hypertension: life course confounding and mendelian randomization tests of causality, Arterioscler Thromb Vasc Biol, 25, nr.5, 2005, p.1051-1056.

28.CHOI, H.K., FORD, E.S., LI, C., CURHAN, G., Prevalence of the metabolic syndrome in patients with gout: the Third National Health and Nutrition Examination Survey. Arthritis Rheum., 57, nr.1, 2007, p. 109-15

29.CHOI, H.K., ATKINSON, K., KARLSON, E.W., CURHAN, G., Obesity, weight change, hypertension, diuretic use, and risk of gout in men: the health professionals follow-up study, Arch Intern Med, 165, nr.7, 2005 , p. $742-8$.
30.MCADAMS-DEMARCO, M.A., MAYNARD, J.W., BAER, A.N., CORESH, $\mathrm{J}$., Hypertension and the risk of incident gout in a population-based study: the atherosclerosis risk in communities cohort, J Clin Hypertens (Greenwich), 14, nr.10, p. 675-9.

31.PAN, A., TENG, G.G., YUAN, J.M., KOH, W.P., Bidirectional Association between Self-Reported Hypertension and Gout: The Singapore Chinese Health Study, PLoS One, 10, nr.10, 2015, e0141749. 32.SUN, H.L., PEI, D., LUE, K.H., CHEN, Y.L., Uric acid levels can predict metabolic syndrome and hypertension in adolescents: a 10year longitudinal study, PLOS ONE, 10, nr.11, 2015, e0143786.

33.WEI, F., SUN, N., CAI, C., FENG, S., TIAN J ., SHI, W., XU, W., WANG, Y., YANG, X., SHI, W., Associations between serum uric acid and the incidence of hypertension: a Chinese senior dynamic cohort study, J Transl Med, 14, nr.1, 2016, p. 110.

34.YOKOI, Y., KONDO, T., OKUMURA, N., SHIMOKATA, K., OSUGI, S., MAEDA, K, MUROHARA, T1., Serum uric acid as a predictor of future hypertension: stratified analysis based on body mass index and age, Prev Med, 9, nr.20, 2016, p. 201-206.

35.CICERO, A.F., ROSTICCI, M., FOGACCI, F., GRANDI, E., D'ADDATO, S., BORGHI. C., High serum uric acid is associated to poorly controlled blood pressure and higher arterial stiffness in hypertensive subjects. Eur J Intern Med, 37, nr.38, 2017, doi: 10.1016/j.ejim. 2016.07.026.

36.VIAZZI, F., REBORA, P., GIUSSANI, M., ORLANDO, A., STELLA, A., ANTOLINI, L., VALSECCHI, M.G., PONTREMOLI, R., GENOVESI, S., Increased serum uric acid levels blunt the antihypertensive efficacy of lifestyle modifications in children at cardiovascular risk, Hypertension, 67, nr.5, 2016, p.934-940.

37.CICERO, A., ROSTICCI, M., TARTAGNI, E., PARINI, A., GRANDI, E., D'ADDATO, S., Serum uric acid level, but not renal function or arterial stiffness, is associated to worse blood pressure control in general practice: data from the brisighella heart study, J Hypertens, 33, Suppl 1,2015 , e22.

38.CHO, J., KIM, C., KANG, D.R., PARK, J., Hyperuricemia and uncontrolled hypertension in treated hypertensive patients: K-MetS study, Medicine (Baltimore), 95, nr.28, 2016, e4177.

39.KUNIKULLAYA, K.U., PURUSHOTTAM, N., PRAKASH, V., MOHAN, S., CHINNASWAMY, R., Correlation of serum uric acid with heart rate variability in hypertension, Hipertens Riesgo Vasc., 32, nr.4, 2015, p. 133-141.

40.CHOI, H.K., SORIANO, L.C., ZHANG, Y., RODRIGUEZ, L.A., Antihypertensive drugs and risk of incident gout among patients with hypertension: population based case-control study, BMJ, 344, nr.1, 2012, d8190, doi: 10.1136/bmj.d8190.

41.RAO, G.N., CORSON, M.A., BERK, B.C., Uric acid stimulates vascular smooth muscle cell proliferation by increasing platelet-derived growth factor A-chain expression, J Biol Chem, 1991, 266, nr.13, p. 8604-8. 42.CHOI YJ, YOON Y, LEE KY, HIEN TT, KANG KW, KIM KC, LEE J, LEE MY, LEE SM, KANG DH, LEE BH. Uric acid induces endothelial dysfunction by vascular insulin resistance associated with the impairment of nitric oxide synthesis. FASEB J. 2014 Jul; 28(7):3197204.

43.PERLSTEIN, T.S., GUMIENIAK, O., HOPKINS, P.N., MURPHEY, L.]., BROWN, N.J ., WILLIAMS, G.H., HOLLENBERG, N.K., FISHER, N.D., Uric acid and the state of the intrarenal renin-angiotensin system in humans, Kidney Int, 66, nr.4, 2004, p. 1465-70.

44.UMEKAWA, T., CHEGINI, N., KHAN, S.R., Increased expression of monocyte chemoattractant protein-1 (MCP-1) by renal epithelial cells in culture on exposure to calcium oxalate, phosphate and uric acid crystals, Nephrol Dial Transplant, 18, nr.4, 2003, p. 664-9

45.TOYODA, K., MIYAMOTO, Y., IDA, M., TADA, S., UTSUNOMIYA, M., Hyperechoic medulla of the kidneys, Radiology, 173, nr.2, 1989, p. 431-4.

46.LI, L., YANG, C., ZHAO, Y., ZENG, X., LIU, F., FU, P., Is hyperuricemia an independent risk factor for new-onset chronic kidney disease?: A systematic review and meta-analysis based on observational cohort studies, BMC Nephrol., 15, nr.15, 2014, p. 122. 
47.SHARAF EL DIN, U.A.A., SALEM, M.M., ABDULAZIM, D.O., Uric acid in the pathogenesis of metabolic, renal, and cardiovascular diseases: A review, J Adv Res., 8, nr.5, 2017 p. 537-548.

48.DUCKWORTH, D. C., A treatise on gout, London: Griffin Co,1889. p. 476.

49.GONG, S., SONG, J., WANG, L., ZHANG, S., WANG, Y., Hyperuricemia and risk of nonalcoholic fatty liver disease: a systematic review and meta-analysis, EurJ Gastroenterol Hepatol., 28, nr.2, 2016, p.132-8.
50.ZHOU, Y., WEI, F., FAN, Y., High serum uric acid and risk of nonalcoholic fatty liver disease: A systematic review and meta-analysis. Clin Biochem., 49, nr.7, 2016, p. 636-42.

51.POPA-WAGNER, A., BUGA, A.M., TICA, A.A., ALBU, C.V., Perfusion deficits, inflammation and aging precipitate depressive behavior, Biogerontology., 15, nr. 5, 2014, p. 439-448.

Manuscript received: 14.05 .2018 